\title{
PENERAPAN DEFERRED PROSECUTION AGREEMENT DI INDONESIA SEBAGAI ALTERNATIF PENYELESAIAN TINDAK PIDANA EKONOMI YANG DILAKUKAN OLEH KORPORASI
}

\author{
Ahmad Iqbal \\ Magister Ilmu Hukum Universitas Indonesia \\ Jl. Salemba Raya IV, RW.5, Kenari, Kec. Senen, Kota Jakarta Pusat, \\ Daerah Khusus Ibukota Jakarta 10430 \\ Email:ahmadiqbal12@gmail.com
}

\begin{abstract}
Abstrak
Korporasi mempunyai peranan penting dalam pembangunan ekonomi suatu negara, namun demikian tidak jarang korporasi dalam aktivitasnya melakukan tindakan menyimpang atau kejahatan dengan berbagai modus operandi. Salah satu cara menyelesaikan tindak pidana yang dilakukan di Inggris adalah Deferred Prosecution Agreement (DPA) yang diatur dalam Schedule 17 of the Crime and Courts Act 2013. DPA sejatinya merupakan pengenyampingan penuntutan secara pidana terlebih dahulu dengan syarat korporasi memenuhi kondisi-kondisi tertentu dalam jangka waktu tertentu. DPA dapat dipertimbangkan oleh penegak hukum Indonesia serta legislator di Indonesia dalam mencoba menyelesaikan tindak pidana korporasi yang merugikan perekonomian negara. Untuk dapat menerapkan DPA di Indonesia harus diaturnya dalam peraturan perundang-undangan dasar dalam menentukan dapatkah korporasi mempunyai tanggungjawab pidana di Indonesia dan juga pengaturan kewenangan jaksa dalam menghentikan penuntutan sementara. Penelitian ini bertujuan untuk mengetahui bagaimana peluang penerapan DPA sebagai penegakan hukum alternatif dalam menyelesaikan tindak pidana ekonomi yang dilakukan oleh korporasi dapat berjalan efektif. Metode yang digunakan untuk mendapatkan data yang diperlukan adalah metode penelitian kualitataif yang mengambil sikap kritis-normatif yang bertolak dari wawasan atau keberadaan manusia dalam masyarakat serta melancarkan kritik terhadap praktik hukum maupun dogmatik hukum. Hasil Penelitian yang didapat adalah DPA digunakan untuk mempercepat pemulihan atas kerugian tindak pidana yang telah dilakukan dan pengembalian aset. DPA berpeluang diterapkan di Indonesia dengan melakukan perubahan dalam peraturan perundang-undangan dan landasan berpikir dari penegak hukum dalam menangani persoalan tersebut jika ingin menerapkan DPA di Indonesia.
\end{abstract}

Kata Kunci: Korporasi, Tanggungjawab pidana, Deferred prosecution agreement.

\begin{abstract}
Corporations have an important role in the economic development of a country, but someway corporations commit crime in a various ways. In United Kingdom, there is a tool for prosecutor that named deferred prosecution agreement, stated in Schedule 17 of the Crime and Courts Act 2013. Essentially, DPA used to deferr criminal prosecution, only if corporation agree to fulfill certains conditions within certain period of time. DPA can be considered by indonesian enforcement as well legislators to resolve corporate criminal acts that harm the country's economy. To implement the DPA in Indonesia, legislator must regulated how corporation could have a criminal responsibilty and how could the prosecutor in deferr prosecution. The method used to obtain data is qualitative research that takes a critical-normative that departs from human insight and criticism of legal practice and dogmatic law. Research results show that DPA used to accelerate recovery from losses caused by criminal act. DPA has the opportunity to be applied in Indonesia by making changes in the laws and regulation, moreover the rationale of law enforcer must be changed if DPA applied in Indonesia.
\end{abstract}




\section{Keywords: Corporation, Criminal liability, Deferred Prosecution Agreement}

\section{A. PENDAHULUAN}

Wacana untuk mengakui korporasi sebagai subjek hukum pidana saat ini masih ingin dikedepankan, terlihat dalam Rancangan Kitab Hukum Acara Pidana yang ingin dimasukan pertanggungjawaban korporasi dalam ketentuannya. Sebelum rancangan tersebut dibuat, pertanggungjawaban korporasi dalam hukum pidana telah tersebar dalam pertaturan perundang-undangan di Indonesia, terutama yang di luar KUHP sekarang. Contohnya Undang-Undang Nomor 8 Tahun 2010 tentang Pencegahan dan Pemberantasan Tindak Pidana Pencucian Uang, Undang-Undang Nomor 41 Tahun 1999 tentang Kehutan, UndangUndang Nomor 32 Tahun 2009 tentang Pengelolaan dan Perlindungan Lingkungan Hidup dan Undang-Undang dan Undang-Undang Nomor 20 Tahun 2001 tentang Perubahan atas Undang-Undang Nomor 31 Tahun 1999 tentang Pemberantasan Tindak Pidana Korupsi. Dalam tingkatan peraturan dibawah undang-undang, tata cara penyelesaian perkara pidana yang menyangkut tindak pidana korupsi juga diatur dalam Peraturan Mahkamah Agung Republik Indonesia Nomor 13 Tahun 2016 tentang Tata Cara Penanganan Perkara Tindak Pidana oleh Korporasi.

Dalam peraturan perundang-undangan tersebut terdapat berbagai macam teori pertanggungjawaban korporasi serta bagaimana cara korporasi bertanggungjawab. Hal ini menandai ketidakseragaman dalam menentukan bagaimana sistem pertanggungjawaban tindak pidana korporasi dan yang sampai saat ini menjadi perdebatan adalah apakah layak korporasi untuk memiliki tanggungjawab secara pidana dengan kaitan bagaimana menentukan unsur kesalahan korporasi. Terlepas dari s215emua perbedaan teori tersebut, urgensi untuk mempidanakan korporasi bukan hanya pengurusnya semakin mencuat dimana terlihat korporasi semakin ikut serta dalam tindak pidana ekonomi di Indonesia. Kenyataan 
telah membuktikan bahwa korporasi kerap berperan dan mengambil keuntungan dalam berbagai peristiwa pidana yang merugikan masyarakat sehingga rasional dan adil jika korporasi bertanggungjawab atas kejahatan yang dilakukan untuk kepentingan korporasi. ${ }^{1}$ Walaupun, korporasi mempunyai peranan penting dalam pembangunan ekonomi suatu negara, namun demikian tidak jarang korporasi dalam aktivitasnya melakukan tindakan menyimpang atau kejahatan dengan berbagai modus operandi. Selain itu dalam derajat hukumannya, pemidanaan korporasi dalam memberikan efek jera serta rehabilitatif , efektifitasnya dapat diberdebatkan telah berhasil atau tidak. Belum lagi tujuan menyelesaikan perkara pidana yang menyangkut korporasi, apakah hanya sekedar menghukum atau menginkan untuk menyelamatkan aset negara yang telah dirugikan dalam tindak pidana tersebut.

Dalam ketentuan Undang-Undang Nomor 7 Tahun 2006 yang merupakan ratifikasi UNCAC dimana pada artikel 26 ayat (4) menyatakan bahwa negara pihak juga wajib mengusahakan agar korporasi yang bertanggungjawab tersebut dikenakan sanksi pidana atau non-pidana yang efektif, proporsional dan bersifat larangan, termasuk sanksi keuangan. Jika sanksi non-pidana secara efektif dan proprsional dianggap lebih berdaya guna menurut penegak hukum dan hakim maka penggunaan hukum pidana dapat dipertimbangkan dan dikesampingkan. Sebagai contoh dalam Hukum Inggris menggunakan Deferred Prosecution Agreeements (DPA). ${ }^{2}$ Penulis memilih DPA Inggris dikarenakan DPA Inggris tersebut masih terhitung baru dalam penerapannya, yaitu mulai pada tahun 2013 dan DPA Inggris memiliki keunikan, yaitu dengan dipertimbangkannya pengaruh korporasi yang dapat melakukan negosiasi DPA terhadap perekonomian negara dan juga dipertimbangkannya

\footnotetext{
${ }^{1}$ Rasamala Aritonang, “Memidana Korporasi,” https://antikorupsi.org/id/opini/memidana-korporasi, diunduh 26 Maret 2019.

2 Budi Suhariyanto, Restoratif Justice dalam Pemidanaan Korporasi Pelaku Korupsi demi Optimalisasi Pengembalian Kerugian Negara," Jurnal Rechtsvinding, Vol. 5 No. 3 Desember 2016, Jakarta: Kementerian Hukum dan HAM, HIm. 432
} 
aspek kepentingan umum. DPA sejatinya merupakan pengenyampingan penuntutan secara pidana terlebih dahulu dengan syarat korporasi memenuhi kondisi-kondisi tertentu dalam jangka waktu tertentu. DPA dapat dipertimbangkan oleh penegak hukum Indonesia serta legislator di Indonesia dalam mencoba menyelesaikan tindak pidana korporasi yang merugikan perekonomian negara.

Belum adanya pengaturan DPA di Indonesia perlu dipertimbangkan dalam menyelesaikan tindak pidana ekonomi yang dilakukan oleh korporasi, karena sampai saat ini penyelesaian tindak pidana ekonomi yang dilakukan oleh korporasi dengan model penegakan hukum saat ini belum memenuhi keadilan, kepastian hukum dan kemanfaatan hukum tetap terlaksana dan mengurangi potensi konflik kepentingan. Di sisi lain, ketimpangan cost and benefit dalam perampasan aset yang besar, dimana biaya dalam melakukan perampasan aset lebih besar dari pada aset yang akan dirampas.

Untuk lebih memfokuskan ruang lingkup yang akan dibahas maka rumusan masalah yang diajukan, yaitu ketentuan Schedule 17 of the Crime and Courts Act 2013 terhadap tindak pidana yang dilakukan oleh korporasi dan peluang penerapan DPA dalam Sistem Hukum Indonesia.

\section{B. METODE PENELITIAN}

Metode yang digunakan untuk mendapatkan data yang diperlukan adalah metode penelitian kualitataif. Kajian hukum mengambil sikap kritis-normatif yang bertolak dari wawasan atau keberadaan manusia dalam masyarakat serta melancarkan kritik terhadap praktik hukum maupun dogmatik hukum. ${ }^{3}$ Penelitian di bidang hukum adalah studi sistematis mengenai aturan hukum, prinsip, konsep, teori, doktrin, putusan kasus, institusi

\footnotetext{
${ }^{3}$ Dennis Lioyd dan M. D. A Freeman, Introduction to Jurisprudence, London: Sweer \& Maxwell Limited, 1994, Hlm. 352.
} 
hukum, masalah hukum, isu atau pertanyaan atau sebuah kombinasi diantara semuanya. ${ }^{4}$

Teknik pengumpulan termasuk pengumpulan data primer dan data sekunder. Sumbersumber bahan penelitian menggunakan data yang tersedia (using availalble data) seperti dokumen publik dan catatan-catatan resmi. ${ }^{5}$ Selain itu, studi dokumen dilakukan dengan menggunakan bahan hukum primer, subside dan tersier.

\section{PEMBAHASAN}

1. Ketentuan Schedule 17 of the Crime and Courts Act 2013 terhadap tindak pidana yang dilakukan oleh korporasi

Indonesia dalam menangani tindak pidana korupsi yang dilakukan oleh korporasi berdasarkan Undang-Undang Nomor 31 Tahun 1999 tentang Pemberantasan Tindak Pidana Korupsi sebagaimana yang telah dirubah dengan Undang-Undang Nomor 20 Tahun 2001 tentang Perubahan Undang-Undang Nomor 31 Tahun 1999 tentang Pemberantasan Tindak Pidana Korupsi (selanjutnya akan disebut sebagai UU PTPK). Dalam Pasal 2, Pasal 3, Pasal 20 UU PTPK diakui bahwa korporasi sebagai subjek hukum yang memiliki pertanggungjawaban pidana dalam tindak pidana korupsi.

Di Inggris penanganan tindak pidana korupsi yang dilakukan oleh korporasi berdasarkan Schedule 17 of the Crime and Courts Act 2013 (selanjutnya akan disebut sebagai Schedule 17 of C\&C Act 2013), dimana kebijakan yang dipakai dalam menangani tindak pidana korupsi yang dilakukan oleh korporasi menggunakan kebijakan DPA (Deffered Prosecution Agreement).

\section{a. Ketentuan Schedule 17 of the Crime and Courts Act 2013}

Schedule 17 of the Crime and Courst Act 2013 mengatur tentang ketentuan Deffered Prosecution Agreement (DPA). DPA adalah sebuah perjanjian yang dilakukan dibawah

\footnotetext{
${ }^{4}$ Anwarul Yaqin, Legal Research and Writing, Malaysia: Lexus Nexis Grup, 2011, Hlm. 3.

${ }^{5}$ Royce Singleton, Approaches to Social Research, Oxford: Oxford University Press, 1988, H1m. 326.
} 
pengawasan hakim, yang dibuat oleh jaksa penuntut umum Inggris (JPU) dengan korporasi yang akan dituntut. ${ }^{6}$ Perjanjian tersebut berisi diperbolehkannya penghentian penuntutan sementara dengan jangka waktu yang ditentukan agar sebuah korporasi dapat memenuhi kondisi-kondisi tertentu.

Tindak pidana yang dapat diterapkan DPA hanya tindak pidana tertentu, yaitu pemufakatan penipuan, penggelapan pajak, pencurian, pemalsuan akutansi, penyuapan dan tindak-tindak pidana ekonomi lainnya yang terdapat dalam ketentuan Theft Act 1968, Customs and Excise Management Act 1979, Forgery and Counterfeiting Act 1981, Section 450 of The Companies Act 1985, Section 72 of the Value Added Tax Act 1994, Financial Services and Markets Act 2000, Proceeds of Crime Act 2002, Companies Act 2006, Fraud Act 2006, Bribery Act 2010, Regulations 45 of the Money Laundering Regulations 2007. DPA hanya dapat diterapkan kepada korporasi bukan kepada individu.

DPA tidak dilaksanakan dalam rangka untuk menghukum seberat-beratnya atau dalam kata lain mematikan korporasi, jika menggunakan prinsip tersebut maka akan mengakibatkan tutupnya korporasi sehingga menyebabkan pengangguran dan menurunya investasi perusahaan. Untuk itu DPA dilaksanakan dengan prinsip:

1. Without Collateral Damage; DPA dilaksanakan kepada korporasi untuk melakukan perbaikan atas tindak pidana yang telah dilakukan tanpa mengenakan hukuman yang menimbulkan collateral damage (sebagai contoh pidana yang akan diterapkan dapat menyebabkan korporasi bangkrut dan menghilangkan lapangan pekerjaan serta investasi orang-orang yang tidak bersalah)

2. Adil dan proposional; DPA dilaksanakan dibawah pengawasan hakim dan dilakukan dengan berkeadilan serta adil dan proporsional

3. Peradilan cepat dan biaya ringan;

4. Transparan.

\footnotetext{
${ }^{6}$ Serious Fraud Office, "Deffered Prosecution Agreement," https://www.sfo.gov.uk/publications/guidancepolicy-and-protocols/deferred-prosecution-agreements/, diunduh 20 April 2019
} 
DPA merupakan suatu diskresi jaksa dengan latar belakang diberlakukannya DPA, yaitu: ${ }^{7}$

1. Penyidikan dan Persidangan yang akan memakan waktu yang lama, biaya besar dan sulit;

2. Penegak hukum Inggris mengalami kesulitan dalam menentukan sanksi yang cocok kepada pelaku, disisi lain kebutuhan untuk memperbaiki korban meningkat;

3. Kesulitannya melakukan penyidikan terhadap tindak pidana yang dilakukan korporasi yang menyangkut lintas batas yurisdiksi negara;

4. Penyidikan membutuhkan kerjasama antar pengak hukum yang komplek dan berbeda.

\section{b. Mekanisme DPA}

Agar Deferred Prosecution Agreement dapat dilaksanakan maka terdapat dua tahapan yang harus dipenuhi agar suatu kasus dapat diterapkan Deferred Prosecution Agreement, tahapan-tahapan tersebut harus dipertimbangkan oleh jaksa dalam menentukan layak apa tidaknya suatu kasus diterapkan Deffered Prosecution Agreement. Tahap-Tahap tesebut ialah: ${ }^{8}$

\section{Tahap Pembuktian}

Dalam tahapan ini jaksa membuktikan apakah apa bukti bahwa tindak pidana telah dilakukan, namun jika tidak ada bukti-bukti yang konkrit dapat dipertimbangkan pula adanya suatu dugaan yang memiliki alasan masuk akal untuk mengatakan bahwa korporasi telah melakukan tindak pidana dan jika dilakukan penyidikan maka akan menemukan bukti-bukti dari dugaan tersebut.

2. Tahap Kepentingan Umum

Kepentingan publik harus dipertimbangkan jaksa dalam menentukan apakah Deferred Prosecution Agreement dapat dilaksanakan. Kepentingan publik yang dimaksud biasanya berkaitan dengan keseriusan dari kejahatan yang telah dilakukan, kesalahan dari korporasi, dan besar kecilnya kerusakan yang ditimbulkan kepada

\footnotetext{
${ }^{7}$ Norton Rose Fulbright, :Deferred Prosecution Agreements-Justice Delayed or Justice Denied ?, ” Asia Pacific Insight, No. 14 Maret 2018, Asia Pasifi: Asia Pacific Insights, Hlm. 4.

${ }^{8}$ Serious Fraud Office \& Crown Presecution Service, "Deffered Prosecution Agreements Code of Practice," Hlm. 3.
} 
korban. ${ }^{9}$ Penentuan layak atau tidaknya diterapkan DPA untuk perusahaan dibebankan kepada objektifitas jaksa itu sendiri sehingga dasar pertimbangannya beda antara satu kasus dengan kasus lainnya.

Kepentingan umum maksudnya adalah mempertimbangkan keseriusan dari perbuatan jahat yang menimbulkan kerugian kepada korban, Seperti dalam kasus sfo v. rolls royce $e^{10}$ salah satu pertimbangan kepentingan publik dalam kasus tersebut adalah kejahatan yang telah dilakukan roll royce telah menyebabkan kerugian yang mendasar terhadap intergritas dan kepercayaan pasar.

Jika tahapan tersebut dipertimbangkan telah terpenuhi, maka jaksa dapat mengundang korporasi tersebut untuk melaksanakan negosiasi DPA. Negosiasi yang dilakukan adalah untuk menentukan kondisi apa yang harus dipenuhi oleh korporasi dalam jangka waktu tertentu.Kondisi-kondisi tersebut dijelaskan dalam pasal 5 yang berbunyi sebagai berikut berikut: ${ }^{11}$

1. membayar denda;

2. keharusan untuk membayar kompensasi kepada korban;

3. mendonasikan sejumlah uang kepada lembaga amal atau pihak ketiga lain yang ditentukan;

4. keharusan untuk mengembalikan setiap keuntungan yang dihasilkan dari tindak pidana;

5. keharusan memperbaikan kebijakan perusahan dan pelatihan karyawan sehingga tidak terjadi lagi tindak pidana tersebut;

6. keharusan untuk berkerjasama dalam investigasi;

7. membayar biaya perkara.

Kondisi-kondisi tersebut bisa dikenakan lebih dari satu tergantung dari negosiasi antara jaksa dan korporasi tersebut. Kondisi-kondisi yang telah ditentukan dan disepakati ini nantinya harus dilakukan dan dipenuhi oleh korporasi dalam jangka waktu tertentu yang juga telah disepakati.

\footnotetext{
${ }^{9}$ Ibid., Hlm. 4.

${ }^{10}$ Case No. U20170036

11 Schedule 17 Crime and Courts Act 2013
} 


\section{Penerapan DPA di Indonesia}

\section{a. Peluang Penerapan DPA}

DPA sebagai alat dalam penegak hukum di Inggris, yaitu jaksa. DPA telah berhasil menjerat beberapa korporasi, yaitu Standard Bank, XYZ Limited, Tesco Plc dan Roll Royce. DPA. Untuk itu bisa menjelaskan peluang penerapan DPA di Indonesia, jika penegak hukum dan legislator berniat untuk menerapkannya, dapat dikemukakan beberapa hal yang menjelaskan hubungan DPA dengan sistem hukum Indonesia. Beberapa hal tersebut sebagai berikut:

1. Unsur kesalahan korporasi

Di Inggris korporasi telah dianggap sebagai subjek hukum yang telah memiliki pertanggungjawaban pidana. Terlihat dalam salah satu undang-undang, yaitu Bribery Act 2010. Pada "Pasal 7" Bribery Act berbunyi:

A relevant commercial organisation ("C") is guilty of an offence under this section if a person ("A") associated with $\mathrm{C}$ bribes another person intending:

(a) to obtain or retain business for $\mathrm{C}$, or

(b) to obtain or retain an advantage in the conduct of business for $\mathrm{C}$.

Sebelum ada ketentuan tersebut, di Inggis korporasi sebagai subjek hukum pidana memang bukanlah hal yang baru, yakni dalam kasus $R v$ Birmingham \& Glocester Railway Co. ${ }^{12}$ Untuk mengasumsikan kesalahan korporasi Inggris memakai teori identifikasi. Doktrin ini berasumsi bahwa semua tindakan legal maupun ilegal yang dilakukan oleh high level manager atau direktur diidentifikasikan sebagai tindakan korporasi. ${ }^{13}$

Denning LJ, dalam perkara H.L Bolton Engineering Co. Ltd v T. J. Graham \& Sons Ltd. menjelaskan teori identifikasi mengibaratkan suatu perusahaan sebagai tubuh manusia, dimana secara lengkap ia mengutarakan: ${ }^{14}$

\footnotetext{
12 R v Birmingham\& Glocester Railway Co. (1842) 3 QB 233

${ }^{13}$ Cristina Maglie, "Models of Corporate Criminal Liability in Comparative Law," Wasinghton University Law Review, Vol. 4 No. 547 Januari 2005, Amerika Serikat: WashingtonUniversity of Law, Hlm. 556.

${ }^{14}$ Sutan Remy Sjahdeini, Pertanggungjawaban Pidana Korporasi, Jakarta:Grafiti Pers, 2006, Hlm. 100.
} 
"A company may in many ways be likende to a human body. It has a brain and nerve centre which controls what it does. It also has hands which hold the tool and act in accordance with directions from the centre. Some of the people in the company are mere servants and agents who are nothing more than hands to do the work and cannot be said to represent the mind or will. Others are directors and managers who represent the directing mind and will of the company, and control what it does. The state of mind of these managers is the state of mind of the company and is treated by the law as such."

Indonesia mengakui korporasi sebagai pemilik pertanggungjawaban pidana dalam tindak pidana korupsi, yaitu berdasarkan ketentuan Pasal 20 UU PTPK. Ditambahkan juga dalam Penjalasan Undang-Undang PTPK, dimana disebutkan bahwa dalam undang-undang tersebut korporasi sebagai subjek tindak pidana korupsi yang dapat dikenakan sanksi dan pada penjelasan pasal 20 (1) disebutkan yang dimaksud dengan "pengurus" adalah organ korporasi yang menjalankan kepengurusan korporasi yang bersangkutan sesuai dengan anggaran dasar, termasuk mereka yang dalam kenyataannya memiliki kewenangan dan ikut memutuskan kebijakan korporasi yang dapat dikualifikasikan sebagai tindak pidana korupsi.

Ketentuan UUPTPK mengatur ruang lingkup tindak pidana yang dapat dimintakan pertanggungjawabannya kepada korporasi. Tindak pidana tersebut adalah penyuapan, perbuatan melawan hukum yang dapat merugikan keuangan atau ekonomi negara, perbuatan curang, pemberian hadian dan tindak pidana lain yang dianggap sebagai tindak pidana korupsi. Dalam historis peraturan perundang-undangan Indonesia, pertanggungjawaban korporasi secara pidana terhadap tindak pidana yang dilakukan, dikenal tiga sistem pertanggungjawaban pidana korporasi, yaitu: ${ }^{15}$

1. Pengurus korporasi sebagai pembuat dan penguruslah yang bertanggungjawab (perkembangan pertanggungjawaban korporasi pada tahap pertama);

2. Korporasi sebagai pembuat namun penguruslah yang bertanggungjawab

\footnotetext{
15 Mardjono Reksodiputro, "Pertanggungjawaban Pidana Korporasi dalam Tindak Pidana Korporasi," Makalah Seminar Nasiona Kejahatan Korporasi, Semarang 23-24 November 1989, Semarang: Fakultas Hukum Undip, HIm. 9.
} 
(perkembangan pertanggungjawaban korporasi pada tahap ke dua)

3. Korporasi sebagai pembuat dan korporasi pula yang harus bertanggungjawab (perkembangan pertanggungjawaban korporasi pada tahap ketiga)

Pendapat lain yang dikemukakan oleh Sutan Remy Sjahdeini, yaitu menambahkan konsep pertanggungjawaban pengurus dan korporasi keduanya sebagai pelaku tindak pidana dan keduanya pula yang harus memikul pertanggungjawaban pidana. Terhadap konsep pertanggungjawaban pengurus dan korporasi, Sutan Remi Sjahdeini berpendapat: ${ }^{16}$

1. Apabila hanya pengurus yang dibebani pertanggungjawaban pidana, maka menjadi tidak adil bagi masyarakat yang telah menderita kerugian karena pengurus dalam melakukan perbuatannya itu adalah untuk dan atas nama korporasi serta dimaksudkan untuk memberikan keuntungan atau menghindarkan mengurangi kerugian finansial bagi korporasi.

2. Apabila yang dibebani pertanggungjawaban pidana hanya korporasi sedangkan pengurus tidak harus memikul tanggungjawab, maka pengurus akan "lempar batu sembunyi tangan".

3. Pembebanan pertanggungjawaban kepada korporasi hanya mungkin dilakukan secara vikarius karena korporasi tidak mungkin dapat melakukan sendiri suatu perbuatan hukum.

Jika menggabungkan kedua pendapat tersebut maka pertanggungjawaban pidana yang terjadi di Indonesia adalah sebagai berikut:

1. Pengurus yang bertanggung jawab;

2. Korporasi yang bertanggungjawab;

3. Korporasi dan pengurus yang bertanggungjawab.

${ }^{16}$ Sutan Remy Sjahdeini, Pertanggungjawaban Pidana Korporasi, Hlm. 162-163. 
Undang-Undang Pemberantasan Tindak Pidana Korupsu (UUPTPK), korporasi secara tegas diatur sebagai subjek hukum yang mempunyai pertanggungjawaban pidana ketika terjadi tindak pidana yang menyangkut korporasi tersebut. Undang-Undang Nomor 31 Tahun 1999 tentang Pemberantasan Tindak Pidana Korupsi sebagaimana telah diubah dengan Undang-Undang Nomor 20 Tahun 2001 tentang Perubahan atas Undang-Undang Nomor 31 Tahun 1999 tentang Pemberantasan Tindak Pidana Korupsi menjadikan korporasi sebagai subjek tindak pidana. Korporasi pertama yang dihukum menggunakan UU PTPK adalah PT. Giri Jaladhi Wana (PT. GJW), PT GJW dihukum setelah sebelumnya pengurusnya yang dihukum terlebih dahulu.

Terdapat juga Peraturan Mahkamah Agung Nomor 13 Tahun 2016 tentang Tata Cara Penanganan Perkara Tindak Pidana oleh Korporasi (PerMa Tata Cara Penanganan Perkara Tindak Pidana oleh Korporasi) juga menentukan bahwa dalam menjatuhkan pidana terhadap Korporasi, Hakim dapat menilai kesalahan Korporasi antara lain:

(a). Korporasi dapat memperoleh keuntungan atau manfaat dari tindak pidana tersebut atau tindak pidana tersebut dilakukan untuk kepentingan Korporasi;

(b). Korporasi membiarkan terjadinya tindak pidana; atau

(c). Korporasi tdak melakukan langkah-langkah yang diperlukan untuk melakukan pencegahan, mencegah dampak yang lebih besar dan memastkan kepatuhan terhadap ketentuan hukum yang berlaku guna menghindari terjadinya tindak pidana.

Dalam Perma Tata Cara Penanganan Perkara Tindak Pidana oleh Korporasi, teori yang dipakai adalah teori the corporate culture model, teori the corporate culture model menentukan bahwa korporasi dapat dipertanggungjawabkan dilihat dari prosedur, sistem bekerjanya atau budayanya. ${ }^{17}$ Untuk jika ingin menerapkan DPA di Indonesia, legislator harus merubah peraturan perundang-undangan secara sistematis, yang mendukung agar korporasi dapat dipidana seperti yang terdapat dalam peraturan perundang-undangan di Inggris.

${ }^{17}$ Barda Nawawi Arief, Kapita Selekta Hukum Pidana, Bandung: Citra Aditya Bakti, 2003, Hlm. 251. 


\section{b. Asas Oportunitas dan Kewenangan Menghentikan Perkara Pidana}

Di Indonesia kewenangan yang dimiliki jaksa untuk tidak meneruskan perkara secara pidana adalah menggunakan asas oportunitas. Asas Oportunitas menurut Andi Hamzah adalah jaksa boleh memutuskan tidak akan menuntut perkara pidana apabila penuntutan itu tidak dapat dilakukan atau tidak patut dilakukan atau tidak dikehendaki atau apabila penuntutan itu lebih merugikan kepentingan umum atau pemerintah daripada apabila penuntutan itu dilakukan. ${ }^{18}$ Penghentian perkara ini hanya dapat dilakukan oleh jaksa agung sebagaimana yang tertuang pada pasal 35 huruf c Undang-Undang No. 16 Tahun 2004, sedangkan yang dimaksud dengan mengkesampingkan perkara demi kepentingan umum dijelaskan dalam penjelasan pasal undang-undang tersebut. ${ }^{19}$ Demi kepentingan umum maksudnya adalah kepentingan bangsa dan negara dan/atau kepentingan masyarakat luas. Menurut Andi Hamzah asas oportunitas dapat dilaksanakan dengan batasan-batasan berikut: ${ }^{20}$

a. Apabila tindak pidana itu menimbulkan kerugian bagi negara dan tidak terhadap kepentingan masyarakat, sedangkan kerugian dari akibat tersebut dirasakan tidak mempengaruhi jalannya pemerintahan

b. Apabila tindak pidana tersebut tidak merugikan bagi kepentingan penyelenggara negara namun berakibat terganggunya kehidupan masyarakat atau timbulkan ketidakadilan dalam masyarakat

Dapat disimpulkan asas oportunitas dilaksanakan jika suatu perkara menimbulkan kerugian bagi negara dan menyebab terganggunya kehidupan masyarakat atau menimbulkan ketidakadilan dalam masyarakat. Tetapi secara legal historis pengenyampingan perkara terjadi pada penyelesaian kasus BLBI, yaitu dengan dikeluarkan Inpres No. 8 Tahun 2002 tentang Release and Discharge. Pada kasus ini, Inpres tersebut mengijinkan perkara BLBI

\footnotetext{
${ }^{18}$ Andi Hamzah dalam Ferdy Saputra, dkk, "Analisis Yuridis Penerbitan Surat Perintah Penghentian Penuntutan Oleh Kejaksaan Dikaitkan Dengan Asas Oportunitas dan Undang-Undang No. 16 Tahun 2004 tentang Kejaksaan RI," Usu Law Journal, Vol. 2 No. 1 Februari 2014, Sumatera Utara: Universitas Sumatera Utara, Hlm. 112.

${ }^{20}$ Ferdy Saputra, “Analisis Yuridis Penerbitan Surat Perintah Penghentian Penuntutan Oleh Kejaksaan Dikaitkan Dengan Asas Oportunitas dan Undang-Undang No. 16 Tahun 2004 tentang Kejaksaan RI," Hlm. 119.
} 
dapat dikesampingkan terlebih dahulu jika para pemegang saham untuk membayar sejumlah kerugian dalam kasus BLBI dengan cara menantangani Akta Pengakuan Utan (APU) yang telah ditetapkan oleh Komite Kebijakan Sektor Keuangan (KKSK), yang selanjutnya pemerintah akan mengeluarkan Surat Keterangan Lunas (SKL) sebagai alasan penghentian penanganan aspek pidananya, dengan jamina SP3 dari Jaksa Agung. ${ }^{21}$ Inpres dikeluarkan untuk merespon kondisi hukum pada saat itu, dimana pasca krisis moneter para koruptor secara berani melakukan korupsi dan penyelesaiannya dgunakan cara yang berani yakni dengan out of court settlement dimana yang diinginkan adalah pengembalian kerugian keuagan negara dengan mengesampingkan prosedur hukum pidana (litigasi). ${ }^{22}$

Meminjam pendapat Satjipto Rahardjo tentang pemiran hukum progresif, penilaian keberhasilan hukum tidak dilihat dari diterapkannya hukum materil maupun formal, melainkan penerapannya yang berani, bermakna dan berkualitas, yaitu adanya keinginan segara dapat mengembalikan situasi perekonomian saat itu (pasca krisis moneter). ${ }^{23}$

Kaitannya dengan DPA memang jaksa dalam melakukan negosiasi dengan korporasi bukan untuk menghentikan perkara tetapi mengkesampingkan dengan batas waktu tertentu dan juga jaksa membertimbangkan kepentingan umum dalam melaksanakan DPA. Jika kondisi-kondisi yang telah dinegosiasikan untuk dipenuhi tidak dilaksanakan oleh korporasi maka kasus tersebut dapat dilanjutkan pidananya. Untuk itu jika ingin menerapkan DPA maka Indonesia membutuhkan peraturan perundang-undangan yang konkrit dan jelas untuk mengatur bagaimana mekanisme penyelesaikan perkara pidana dengan mengkesampingkan tuntutan pidananya terlebih dahulu.

\footnotetext{
${ }^{21}$ Aang Achmad, "Kajian Kasus BLBI: Pergeseran Hukum Publik ke Dalam Lapangan Hukum Privat," Mimbar Hukum, Vol. 23 No. 3 Oktober 2011, Yogyakarta: Universitas Gadjah Mada, Hlm. 604.

${ }^{22}$ Ibid., Hlm. 605.

${ }^{23}$ Satjipto Rahardjo dalam Aang Achmad, “Kajian Kasus BLBI Kajian Kasus BLBI: Pergeseran Hukum Publik ke Dalam Lapangan Hukum Privat, Hlm. 605.
} 


\section{c. Pertimbangan dalam Menerapkan DPA di Indonesia}

Sistem peradilan pidana Indonesia perlu dipertimbangkan dalam mengadaptasi DPA, hal ini sesuai model penegakan hukum terhadap tindak pidana korupsi yang ditentukan, yaitu pengembalian kerugian negara akibat tindak pidana korupsi dan mempertimbangkan memberikan pengurangan hukuman bagi tersangka atau terdakwa. Asas oportunitas yang ada dalam model penegakan hukum di Indonesia masih belum mengakomodir ketentuanketentuan yang ada dalam UNCAC.

Dalam penerapan DPA di Indonesia untuk itu perlu mempertimbangkan hal-hal sebagai berikut: ${ }^{24}$

a. DPA yang akan diterapkan di Indonesia harus mempertimbangkan sistem peradilan Indonesia dalam susunan konstitusional dan tradisi hukum. Dampak beban regulatory and compliance bagi korporasi, dimana korporasi membutuhkan biaya tambahan.

b. Kejahatan yang dapat menggunakan mekanisme DPA termasuk kejahatan serius (tapi tidak terbatas), sehingga perlu dibentuk undang-undang khusus yang mengatur hal tersebut.

c. DPA hanya diberlukakan bagi korporasi maka ada kesempatan untuk memberikan efek pencegahan dan kemungkinan menuntut karyawan (organ perusahaan). Namun jika terbatas hanya pada korporasi, maka timbul kemungkinan individu telah berbuat kejahatan tapi enggan melapor karena takut akan dipidana.

d. Peran pengadilan akan sangat penting bagi DPA. Keterlibatan yudisial akan meningkatkan kepercayaan.

e. DPA harus dibuat seimbang antara kepentingan membangun kepercayaan publik dan juga kepentingan untuk mengejar korporasi yang curang.

f. Untuk meningkatkan kepercayaan publik, skema DPA Indonesia dapat mensyaratkan kesepakatan untuk kepentingan publik dan bersikap adil, masuk akal dan proporsional.

g. Perlu adanya panduan yang jelas mengenai bagaimana DPA akan dinegosiasikan dan mekanisme pengawasan yang efektif.

Hal-hal diatas patut dipertimbangkan dalam menerapkan DPA di Indonesia sehingga keadilan, kepastian hukum dan kemanfaatan hukum tetap terlaksana dan untuk mengurangi potensi konflik kepentingan.

\footnotetext{
${ }^{24}$ Febby Mutiara, "Peradilan Sederhana, Cepat, dan Biaya Ringan: Menggagas Penanganan Tindak Pidana Korupsi Melalui Konsep Plea Bargaining dan Defered Prosecution Agreement," Disertasi, Depok: Universitas Indonesia, 2019.
} 


\section{Kesimpulan}

Ketentuan Undang-Undang Pemberantasan Tindak Pidana Korupsi dan Schedule 17 of the Crime and Courts Act 2013, mengisyaratkan suatu alat penegakan hukum untuk menangani tindak pidana yang dilakukan oleh korporasi. Alat tersebut ialah DPA, DPA menjadi diskresi jaksa penuntut di Inggris untuk mengenyampingkan penuntutan pidana terlebih dahulu dengan syarat korporasi yang melakukan tindak pidana harus melakukan kondisi-kondisi yang telah ditentukan dalam jangka waktu tertentu dan sudah dinegosiasikan terlebih dahulu. DPA hanya dapat diterapkan kepada korporasi dan juga tidak bisa setiap kasus pidana yang menyangkut korporasi dapat diterapkan DPA, jaksa harus mempertimbangkan kepentingan umum yang menyangkut berbagai macam aspek salah satunya mempertimbangkan keseriusan dari perbuatan jahat yang menimbulkan kerugian kepada korban, Seperti dalam kasus sfo v. rolls royce salah satu pertimbangan kepentingan publik dalam kasus tersebut adalah kejahatan yang telah dilakukan roll royce telah menyebabkan kerugian yang mendasar terhadap intergritas dan kepercayaan pasar. DPA digunakan untuk mempercepat pemulihan atas kerugian tindak pidana yang telah dilakukan dan pengembalian aset. DPA jika ingin diterapkan di Indonesia harus dipertimbangkan halhal berikut. Seperti, penentuan apakah layak korporasi untuk dipidana dengan mempertimbangkan unsur kesalahan dimana dalam tiap peraturan perundang-undangan belum mencapai keseragaman teori apa yang ingin digunakan dan bagaimana cara melakukan penghentian penuntutan sementara oleh jaksa, dimana dalam peraturan perundang-undangan hanya ada penghentian penuntatan untuk kepentingan umum yang dinamakan asas oportunitas. Padahal yang sudah dijelaskan sebelumnya DPA bukan untuk menghentikan atau menutup penuntutan selamanya, tetapi hanya mengenyampingkan penuntutan secara pidana asalkan dapat memenuhi syarat-syarat yang telah disepakati. Untuk itu harus ada perubahan dalam peraturan perundang-undangan dan landasan berpikir dari 
penegak hukum dalam menangani persoalan tersebut jika ingin menerapkan DPA di Indonesia.

\section{DAFTAR PUSTAKA}

\section{Peraturan Perundang-undangan:}

Republik Indonesia, Undang-Undang Nomor 20 Tahun 2001 tentang Perubahan Atas Undang-Undang Nomor 31 Tahun 1999 tentang Pemberantasan Tindak Pidana Korupsi, Tambahan Lembaran Negara Republik Indonesia Nomor 4150.

Republik Indonesia, Peraturan Mahkamah Agung Nomor 13 Tahun 2016 tentang Tata Cara Penanganan Perkara Tindak Pidana oleh Korporasi, Berita Negara Republik Indonesia Nomor 2058.

Republik Indonesia, Undang-Undang Nomor 16 Tahun 2015 tentang Kejaksaan Republik Indonesia, Lembaran Negara Republik Indonesia Nomor 67.

United Kingdom, Schedule 17 Crime and Courts Act 2013

\section{Buku:}

Arief, Barda Nawawi. 2003. Kapita Selekta Hukum Pidana, Bandung: Citra Aditya Bakti.

Lioyd, Dennis dan M. D. A Freeman. 1994. Introduction to Jurisprudence, London: Sweer \& Maxwell Limited.

Serious Fraud Office \& Crown Presecution Service, "Deffered Prosecution Agreements Code of Practice,"

Singleton, Royce. 1988. Approaches to Social Research, Oxford: Oxford University Press.

Sjahdeini, Sutan Remy. 2006. Pertanggungjawaban Pidana Korporasi, Jakarta: Grafiti Pers.

Yaqin, Anwarul. 2011. Legal Research and Writing, Malaysia: Lexus Nexis Grup.

\section{Karya Ilmiah:}

Reksodiputro, Mardjono, "Pertanggungjawaban Pidana Korporasi dalam Tindak Pidana Korporasi," Makalah Seminar Nasiona Kejahatan Korporasi, , Semarang: Fakultas Hukum Undip, 23-24 November 1989.

Achmad, Aang, "Kajian Kasus BLBI: Pergeseran Hukum Publik ke Dalam Lapangan Hukum Privat," Mimbar Hukum, Vol. 23 No. 3 Oktober 2011, Yogyakarta: Universitas Gadjah Mada. 
Fulbright, Norton Rose, "Deferred Prosecution Agreements-Justice Delayed or Justice Denied ?," Asia Pacific Insight, No. 14 Maret 2018, Asia Pasifi: Asia Pacific Insights.

Maglie, Cristina, "Models of Corporate Criminal Liability in Comparative Law," Wasinghton University Law Review, Vol. 4 No. 547 Januari 2005, Amerika Serikat: Washington University of Law.

Nelson, Febby Mutiara, "Peradilan Sederhana, Cepat, dan Biaya Ringan: Menggagas Penanganan Tindak Pidana Korupsi Melalui Konsep Plea Bargaining dan Defered Prosecution Agreement," Disertasi, Depok: Universitas Indonesia, 2019.

Saputra, Ferdy, dkk, "Analisis Yuridis Penerbitan Surat Perintah Penghentian Penuntutan Oleh Kejaksaan Dikaitkan Dengan Asas Oportunitas dan Undang-Undang No. 16 Tahun 2004 tentang Kejaksaan RI," Usu Law Journal, Vol. 2 No. 1 Februari 2014, Sumatera Utara: Universitas Sumatera Utara.

Suhariyanto, Budi, "Restoratif Justice dalam Pemidanaan Korporasi Pelaku Korupsi demi Optimalisasi Pengembalian Kerugian Negara," Jurnal Rectsvinding, Vol. 5 No. 3 Desember 2016, Jakarta: Kementerian Hukum dan HAM.

\section{Sumber lainnya:}

Rasamala Aritonang, "Memidana Korporasi," https://antikorupsi.org/id/opini/memidanakorporasi, diunduh 26 Maret 2019.

Serious Fraud "Defered Prosecution Agreement," https://www.sfo.gov.uk/publications/guidance-policy-and-protocols/deferredprosecution-agreements/, diunduh 20 April 2019 